\title{
AKULTURASI NILAI BUDAYA MELAYU DAN BATAK TOBA PADA MASYARAKAT MELAYU KOTA TANJUNGBALAI ASAHAN
}

\author{
Mailin \\ Fakultas Ilmu Dakwah dan Komunikasi UIN Sumatera Utara, Medan \\ Jl. Willem Iskandar Pasar V Medan Estate, Medan, Sumatera Utara, 20371 \\ e-mail: mailin77@ymail.com
}

\begin{abstract}
This paper attempts to analyze the acculturation process of Malays and Toba Batak cultures in Asahan Tanjungbalai, and to what extent the Sultan of Asahan influenced the process of acculturation. This study uses descriptive qualitative research method. The findings of this research showed that the process of acculturation Malay and Muslim Toba Batak culture in the city emerged from the government of Tanjungbalai Sultan Asahan I who ruled in the city before the independence era of the Republic of Indonesia. Religious leaders (ulama) and traditional leaders also played a role in the acculturation process of Malay cultural values in Tanjungbalai, especially in the Batak Toba ethnic Muslim milieu. Acculturation between these two cultures gave birth to a Malay culture which led to a different characteristic to the Malay culture in the archipelago. The author affirms that Malays in the city, by nature, tends to be tough in character as a result of Toba Batak ethnic character.
\end{abstract}

\begin{abstract}
Abstrak: Acculturation of the Malay and Toba Batak Cultural Values on Malay Societies in Tanjung Balai City Asahan North Sumatra. Penelitian ini adalah penelitian lapangan yang bertujuan untuk mengetahui proses akulturasi budaya Melayu dan Batak Toba di Tanjungbalai Asahan, serta seberapa besar pengaruh Sultan Asahan dalam proses akulturasi budaya Melayu dan Batak Toba di Asahan. Penelitian ini menggunakan metode penelitian kualitatif deskriptif. Hasil penelitian menunjukkan bahwa proses akulturasi budaya Melayu dan budaya Batak Toba Muslim di kota Tanjungbalai berawal dari pemerintah Sultan Asahan I yang memerintah di kota Tanjungbalai sebelum kemerdekaan Negara Republik Indonesia. Tokoh agama (ulama) dan tokoh adat juga turut berperan dalam proses akulturasi nilai budaya Melayu di Kota Tanjungbalai, khususnya pada etnis Batak Toba Muslim. Akulturasi antar dua budaya ini melahirkan sebuah budaya Melayu yang memiliki ciri khas yang berbeda dengan budaya Melayu di Nusantara. Melayu di kota ini memiliki sifat serta karakter yang cenderung kasar dan keras, seperti karakter etnis Batak toba.
\end{abstract}

Kata Kunci: Melayu, Batak Toba, Kesultanan Asahan, Tanjungbalai, Nusantara 


\section{Pendahuluan}

Secara teoretis, budaya adalah komunitas makna dan sistem pengetahuan bersama yang bersifat lokal. ${ }^{1}$ Kebudayaan merupakan wujud dari budi daya manusia yang mencakup berbagai pengetahuan, kepercayaan, kesenian, moral, hukum, adat serta kemampuan dan kebiasaan lainnya yang diperoleh manusia sebagai makhluk sosial. Budaya adalah salah satu yang membatasi dan mengarahkan perilaku. ${ }^{2}$ Budaya memuat aturan bagaimana manusia berhubungan dengan orang lain, berpikir, dan bertingkah laku. Menurut Koentjaraningrat, kebudayaan adalah keseluruhan sistem gagasan, tindakan, dan hasil karya dalam kehidupan masyarakat, yang dijadikan milik dari manusia yang belajar. ${ }^{3}$ Menurut E. B. Taylor, kebudayaan adalah hal kompleks yang mencakup pengetahuan, kepercayaan, kesenian, moral, hukum, adat istiadat dan lain-lain, kemampuan-kemampuan serta kebiasaankebiasaan yang didapat manusia sebagai anggota masyarakat. ${ }^{4}$ Kajian budaya telah mendapatkan perhatian dari banyak ahli, khususnya budaya masyarakat di Indonesia.

Sebelum Indonesia menjadi negara merdeka, Indonesia merupakan beberapa gugusan kepulauan Nusantara. Daerah-daerah dikuasai oleh beberapa kerajaan yang dipimpin oleh raja/sultan. Di antara kesultanan di Indonesia berpusat di daerah Sumatera Timur. Kawasan ini terdiri atas beberapa kerajaan Melayu seperti Kerajaan Langkat, Melayu Deli, Serdang, Batu Bara, Asahan, Kualuh, Bilah, Panai dan Pinang Awan. Secara geografis, etnis Melayu di Indonesia terdapat di Kalimantan Barat, Riau, Jambi, Palembang, pesisir timur Sumatera Utara, dan Aceh Timur.

Salah satu Kesultanan Melayu di Indonesia adalah Kesultanan Melayu Asahan. Kesultanan Asahan pernah diperintah sebelas orang raja. Pusat kerajaan berada di Tanjungbalai. Jika dilihat secara geografis, wilayah Asahan dibatasi dengan daerah Tapanuli Utara yang terkenal sebagai daerah Batak, dan suku Batak ini terkenal dengan sifat yang keras. Hal ini merupakan tantangan bagi kesultanan dalam menyebarkan adat istiadat Melayu dan agama Islam di Asahan. Seiring penyebaran Islam ke seluruh Nusantara, nilai-nilai Islam (Melayu) berangsur-angsur menyatu dengan tradisi, norma, dan kehidupan sehari-hari masyarakat Batak. Di era kesultanan, masyarakat dari suku Batak Toba meninggalkan kampung halaman mereka dengan sejumlah alasan, dan berdomisili di Sumatera Timur yang dikuasai oleh sejumlah kesultanan Melayu yang sangat fanatik dengan Islam. Fakta ini membuat masyarakat Batak yang non-Muslim harus mampu beradaptasi dengan kondisi setempat. Kondisi ini akhirnya menggiring terjadinya akulturasi kebudayaan di Tanjungbalai

${ }^{1}$ Richard West dan Lynn H. Turner, Pengantar Teori Komunikasi: Analisis dan Aplikasi, terj. Maria Natalia Damayanti Maer (Jakarta: Salemba Humanika, 2009), h. 42.

${ }^{2}$ Larry A. Samovar, dan Richard E Porter, Komunikasi Lintas Budaya, terj. Indri Margaretha Sidabalok (Jakarta: Salemba Humanika, 2010), h. 26- 28.

${ }^{3}$ Koentjaraningrat, Pengantar Antropologi, Jilid II (Jakarta: Rineka Cipta, 2005), h. 11.

${ }^{4}$ Soerjono Soekanto, Sosiologi: Suatu Pengantar (Jakarta: Rajawali Pers, 1987), h. 154. 
selamat era kesultanan sampai saat ini. Fakta menunjukkan bahwa telah terjadi akulturasi ${ }^{5}$ budaya antara budaya Melayu dan Batak Toba di Tanjungbalai.

Berdasarkan keterangan Bapak Raja Chairil Anwar ${ }^{6}$ mengenai sejarah Kesultanan Melayu di Tanjungbalai Asahan bahwa "pada masa pemerintahan Sultan, setiap orang yang ingin tinggal menetap dan memiliki tempat tinggal (tanah dan rumah) di kota ini harus masuk Melayu". Kata "masuk Melayu" di sini dipahami dengan masuk Islam (menjadi Muslim). Hal ini sangat berpengaruh bagi masyarakat yang datang ke daerah ini, terutama yang tidak beragama Islam. Salah satu suku yang melakukan migrasi ke kota ini adalah suku Batak Toba, yang akhirnya harus meninggalkan adat budaya asalnya, kemudian memakai adat budaya Melayu ketika mereka tinggal menetap di kota Tanjungbalai dan masuk Islam. Hal ini sejalan dengan pendapat Nagata tentang Melayu bahwa "It is almost imposible to think of Malay without reference to Islam". ${ }^{7}$ Akhirnya, Islam menjadi pegangan hidup, dan dianggap sebagai budaya bagi mereka. Dapat dilihat bahwa Melayu (Islam) berhasil menyebarkan dan menanamkan ajaran agama Islam, dan budaya Melayu pada komunitas yang umumnya telah memiliki tradisi atau adat istiadat yang sudah diwarisi secara turun temurun dari nenek moyang mereka. Sampai pada tahun 1946, Tanjungbalai Asahan masih dikuasai oleh Kesultanan Asahan. Kemudian, sistem Kesultanan Asahan diambil alih oleh pemerintahan setelah digulingkan oleh sebuah pergerakan sosial anti kaum bangsawan (feodal) yang dikenal dalam catatan sejarah Melayu dengan peristiwa berdarah "Revolusi Sosial." ${ }^{\text {M }}$ Menarik dikaji bahwa masyarakat Batak Toba harus masuk "Melayu" (Islam) apabila ingin berdomisili di Tanjungbalai sebagai salah satu kawasan kekuasaan Kesultanan Asahan, sehingga akan menarik dilihat bagaimana proses akulturasi budaya pada masa yang dikaji.

\section{Metode Penelitian}

Secara khusus, artikel ini akan mengkaji akulturasi nilai budaya Melayu dan Batak

5oan Marshall \& Natalie Foster, "Between Belonging: Habitus and The Migration Experince," dalam Canadian Geographer, Spring, 2002, 46. 1, h. 66; You-Jin Chung Chung \& Jayashree Mohanty, "Between Two Worlds in Asia: Korean Youth in Singapore," dalam Springer Science Business Media Dordrecht, 29 July 2014, h. 226-231; Montgomery Schwartz \& Briones, "The Role of Identity in Acculturation among Immigrant People: Theoretical Propositions, Empirical Questions, and Applied Recommendations," dalam Human Development, 49, 1-30, h. 1; Vijayasarathi Ramanathan, "Values, Behaviour and Identity: Acculturation of Indian Immigrant Men in Australia," dalam Springer Science Business Media Dordrecht, 24 June 2014, h. 635.

${ }^{6}$ Hasil wawancara dengan Bapak Raja Chairil Anwar (raja Atan adalah Ketua Forum Komunikasi Keluarga Besar Kesultanan Tanjungbalai Asahan), 6 April 2015.

${ }^{7}$ Judith Nagata, The Impact of the Islamic Revival (Dakwah) on the Religious Culture of Malaysia, dalam Bruce Matthews dan Judith Nagata (ed.), Religion, Values, and Development in Southeast Asia (Singapore: Institute of Southeast Asian Studies, 1986), h. 37.

${ }^{8}$ Lihat Tengku Luckman Sinar Basyarsah II, Bangun dan Runtuhnya Kerajaan Melayu di Sumatera Timur (Medan: Yayasan Kesultanan Serdang, 2006, h. 483- 485. 
Toba di Tanjungbalai Asahan. Untuk menjawab rumusan masalah, penelitian ini menggunakan pendekatan kualitatif deskriptif. Melalui penelitian deskriptif ini dimaksudkan untuk mendeskripsikan budaya Melayu terutama proses akulturasi budaya Melayu dan Batak Toba Muslim di kota Tanjungbalai. Untuk memahami bagaimana proses akulturasi budaya tersebut, peneliti menggunakan teknik yang biasa digunakan dalam penelitian kualitatif, yaitu observasi berperan serta dan wawancara mendalam. Informan dalam penelitian ini merupakan orangorang yang terkait langsung dengan proses akulturasi nilai-nilai budaya Melayu dan Batak Toba Muslim di Kota Tanjungbalai. Teknik pengumpulan data dilakukan dengan cara mengamati secara langsung seluruh aktivitas masyarakat, baik yang berhubungan dengan budaya Melayu dan budaya Batak Toba, serta pengaruh budaya masing-masing dalam masyarakat kota Tanjungbalai khususnya etnis keturunan Batak Toba Muslim. Teknik kedua, wawancara dengan beberapa pemimpin dan pemuka adat Melayu dan Batak Toba Kota Tanjungbalai. Selain itu, akan ditelaah sejumlah dokumen terkait sejarah berdirinya Kesultanan Asahan di Tanjungbalai Asahan.

\section{Hasil dan Pembahasan}

\section{Kota Tanjungbalai Asahan}

Terkait asal nama Kota Tanjungbalai, menurut cerita yang populer di tengah masyarakat, kata ini berasal dari "balai" yang terdapat di sebuah kampung di sekitar ujung tanjung di muara Sungai Silau dan aliran Sungai Asahan. Balai ini ramai disinggahi orang-orang yang melintas, para pelaut, dan pedagang karena tempatnya yang strategis sebagai bandar kecil. Kemudian kampung ini dinamai Kampung Tanjung, dan orang lazim menyebutnya balai di Tanjung. ${ }^{9}$ Balai inilah yang menjadi cikal bakal Tanjungbalai semakin ramai dan berkembang menjadi sebuah negeri yang diperintah oleh seorang sultan dengan sultan pertama bernama Sultan Abdul Jalil dari kerajaan Asahan pada tahun 1620.

Tanjungbalai diperintah oleh sebelas orang raja. Dimulai dari raja pertama Sultan Abdul Jalil Rahmad Syah (1620) sampai dengan Sulthan Syuaibun Abdul Jalil Rahmad Syah (1933). Hingga tahun 1946, Asahan merupakan salah satu Kesultanan Melayu. Berdasarkan perintah Sultan, bahwa seluruh masyarakat yang tinggal atau merantau ke Tanjungbalai harus masuk Melayu (Islam). Di sini terlihat bahwa kesuksesan ulama dalam menyebarkan Islam, di antaranya disebabkan oleh hubungan dekat mereka dengan Sultan, baik melalui hubungan perkawinan, maupun melalui perannya sebagai penasihat kerajaan. Selain itu, Islam memainkan peranan utama dalam transformasi kerajaan yang berdasarkan golongan tertentu menjadi kerajaan sentralistik yang berdasarkan ikatan darah. Ikatan tersebut sangat berpengaruh dalam proses Islamisasi berbagai suku yang datang ke Asahan.

${ }^{9}$ Watni Marpaung, Mutiara Kota Kerang Tanjungbalai: Mengungkap Sejarah Asal Usul Nama, Adat Istiadat, Tradisi, Makanan Daerah, Kesenian, Pendidikan, dan Sosial Budaya (Medan: Badan Perpustakaan, Arsip dan Dokumentasi Provinsi Sumatera Utara, 2011), h. 1 
Pada 1946, Kesultanan Asahan runtuh akibat adanya gerakan sosial anti kaum bangsawan dalam sebuah Revolusi Sosial di Sumatera Timur dimana hampir semua anggota kesultanan menjadi sasaran kekerasan masyarakat. ${ }^{10}$

Pada saat ini, Kota Tanjungbalai adalah kota yang memiliki ikon "Balayar Satujuan Batambat Satangkahan" yang berarti satu kata dalam mencapai tujuan, serta Monumen Air Mancur dan Ikan Lumba-Lumba yang berada di pusat kota menunjukkan kota yang heterogen. Luas wilayah kota Tanjung Balai $6.052 \mathrm{Ha}\left(60,52 \mathrm{~km}^{2}\right)$ yang diapit Sungai Asahan dan Sungai Silau dengan jembatan terpanjang di Provinsi Sumatera Utara ( $\pm 600 \mathrm{~m}$ ) yang menghubungkan kota Tanjungbalai dengan Desa Sei Kepayang. Kota Tanjung Balai secara administratif terdiri dari 6 Kecamatan, dan 31 Kelurahan. Kecamatan terluas adalah kecamatan Datuk Bandar dengan luas wilayah 2.249 Ha atau sekitar 37,16 persen dari luas kota Tanjungbalai. Kecamatan terkecil adalah kecamatan Tanjungbalai Utara dengan luas 84 Ha atau sekitar 1,39 persen dari luas kota Tanjungbalai. ${ }^{11}$ Kota Tanjungbalai merupakan pemekaran dari Kabupaten Asahan, sehingga tidak mengherankan kalau Tanjungbalai dikelilingi dan berbatasan dengan wilayah Kabupaten Asahan.

Jika dilihat dari batas-batas wilayah kota Tanjungbalai dengan kabupaten Asahan, Tanjungbalai sebenarnya tidak memiliki laut karena daerah laut berada di sebelah Timur dan Utara berbatasan dengan kabupaten Asahan yang dibatasi oleh sebuah desa yaitu Bagan Asahan. Namun, karena sebelah Timur dan Utara kota Tanjungbalai dikelilingi laut yang berjarak $4 \mathrm{~km}$ dari pinggir pantai, kebanyakan penduduk Tanjungbalai memilih untuk menjadi nelayan dan pelaut sebagai profesi dalam kehidupan. ${ }^{12}$ Selain itu, Tanjungbalai juga merupakan "Kota Pelabuhan" sejak masa Hindia Belanda.

Menurut data Pemerintah Kota Tanjungbalai, penduduk kota ini cukup majemuk. Mayoritas penduduk berasal dari suku bangsa Batak (Simalungun, Tapanuli, Toba, Pakpak) 42,56 persen, diikuti dengan suku Jawa 17,06 persen, Melayu 15,41 persen, Minang 3,58 persen, Aceh 1,11 persen, dan lainnya 20,28 persen. ${ }^{13}$ Namun perlu ditegaskan bahwa

${ }^{10}$ Revolusi Sosial adalah pengganyangan terhadap kaum "feodal" oleh orang-orang kiri dan antek-anteknya. Tuduhan mereka ialah para bangsawan sudah membentuk apa yang disebut "Komite van Ontvangst" untuk menyambut kedatangan Belanda, dan tuduhan inilah yang dianggap mereka benar untuk mendasari digerakkannya Revolusi Sosial. Ibid, h. 483-485.

${ }^{11}$ Kota Tanjungbalai Dalam Angka 2014 (Tanjungbalai in Figures 2014) (Tanjungbalai: Badan Pusat Statistik Kota Tanjungbalai, 2014), h. 67.

${ }^{12}$ Nelayan dan pelaut merupakan profesi pekerjaan bagi sebagian besar masyarakat Tanjungbalai, dalam hal ini ada perbedaan antara nelayan dan pelaut. Nelayan adalah orang yang pekerjaan sehari-hari nya sebagai penangkap ikan, baik itu kapal kecil maupun kapal besar. Pelaut adalah orang yang pekerjaannya di laut, seperti kapal penumpang atau kapal pembawa barang-barang ekspor dan impor baik dalam maupun luar negeri, juga kapal pembawa barang-barang makanan ke pulau-pulau lain seperti Batam, Tanjungpinang, Bengkalis, Dumai dan Selat Panjang. Pusat bahasa Departemen Pendidikan Nasional, Kamus Umum Bahasa Indonesia (Jakarta: Balai Pustaka, 2006), h. $798,859$.

${ }^{13}$ Hasil wawancara dengan bapak Murni Panjaitan, 18 Mei 2015. 
walaupun populasi jumlah penduduk etniss Batak lebih dominan, tetapi nuansa corak kebudayaan Melayu sangat jelas terlihat dalam kehidupan masyarakatnya. Hal ini jelas berkaitan dengan akar sejarah kota Tanjungbalai yang berhubungan langsung dengan Kesultanan Malayu yang pernah berkuasa di Tanjungbalai Asahan. Sedangkan agama yang dianut masyarakat Tanjungbalai adalah mayoritas agama Islam (81,99 persen), Buddha (9,07 persen), Kristen Protestan 7,78 persen, Kristen Khatolik 1,06 persen, dan Hindu 0,08 persen dan lainnya 0.02 persen. Kerukunan umat beragama terjalin dengan baik di kota ini. Kenyataan ini tentu saja selain berkaitan dengan kultur masyarakat yang telah menyatu dalam satu kebudayaan, juga berkaitan dengan keberhasilan akulturasi agama dengan budaya lokal sehingga agama tidak menjadi sesuatu yang harus dipertentangkan dengan agama lainnya.

\section{Sistem Sosial Masyarakat Melayu Tanjungbalai}

\section{Struktur Masyarakat}

Struktur kehidupan masyarakat Melayu pada umumnya dibagi dalam dua golongan, yaitu golongan bangsawan dan golongan rakyat atau kebanyakan. Golongan bangsawan sudah ada sejak adanya kerajaan yang kemudian membedakan antara golongan bangsawan dengan golongan rakyat atau kebanyakan. Dapat dilihat dengan jelas status seseorang apakah dari golongan bangsawan atau dari rakyat, dari gelar yang ada di depan namanya. Masing-masing urutan gelar diberikan berdasarkan martabat dan kedudukannya dalam masyarakat, seperti Tengku, Raja, Wan, Datuk, Jaya, Orang Kaya (OK), dan Encek/Tuan. Gelar tengku adalah gelar yang hanya dipakai oleh keturunan Sultan dan kerabatnya serta turunan yang datu-nininya dulu mempunyai daerah otonom sendiri serta biasa dipanggil dengan sebutan Tuanku. Tengku sendiri dapat diartikan dengan berbagai arti seperti pemimpin atau guru, baik dalam akhlak, agama serta adat. Sementara dalam konteks kebangsawanan, seseorang dapat memakai gelar tengku apabila ayahnya bergelar tengku.

Gelar raja yang diberikan dalam kekerabatan Melayu adalah status gelar bangsawan yang diturunkan melalui hubungan darah, bukan sebagai kedudukan dalam pemerintahan untuk memimpin sebuah kerajaan. Oleh pihak Belanda gelar raja diberikan baik kepada mereka yang mempunyai wilayah pemerintahan hukum yang luas ataupun hanya mengepalai sebuah kampung kecil saja, sebagai ketua atau kepala. Menurut keterangan Sultan Deli, Tengku Amaluddin II, yang termaktub dalam suratnya yang ditujukan kepada Gubernur Sumatera Timur tahun 1933, bahwa jika seorang perempuan dengan gelar Tengku menikah dengan seorang yang bergelar Raden dari Tanah Jawa atau seorang yang bergelar Sutan dari Pagarruyung Sumatera Barat, maka gelar Raja berhak dipakai bagi keturunan atau anak-anak yang lahir dari pernikahan tersebut.

Gelar wan akan diberikan kepada perempuan Melayu, apabila perempuan yang bergelar Tengku menikah dengan seorang yang bukan Tengku atau dengan orang kebanyakan, 
maka anak-anaknya berhak memakai gelar wan. Bagi anak laki-laki dan keturunannya berhak memakai gelar ini. Sedangkan untuk anak wanita tergantung dengan siapa dia menikah. Jika suaminya lebih rendah dari wan, maka gelar ini akan hilang dan tidak berhak dipakai anaknya dan keturunannya, karena keturunanya akan mengikuti gelar suaminya.

Gelar kebangsawanan datuk awalnya dari kesultanan Aceh baik langsung maupun melalui perantara Sultan Aceh di Deli. Gelar ini diberikan kepada seseorang yang mempunyai kekuasaan daerah pemerintahan otonomi yang dibatasi oleh dua aliran sungai. Batasbatas ini disebut dengan kedatukan atau kejeruan. Anak-laki-laki turunan dari datuk berhak atas gelar datuk pula, sedangkan untuk anak datuk yang perempuan berhak mendapat gelar saja. Sultan atau Raja dapat memberikan gelar datuk kepada seseorang yang dianggap berjasa untuk kerajaan. Adapun encek/tuan merupakan panggilan kehormatan untuk masyarakat biasa.

\section{Sistem Kekerabatan}

Sistem kekerabatan dalam keturunan pada masyarakat Melayu kota Tanjungbalai adalah prinsip bilateral yang menghitungkan hubungan kekerabatan melalui pria maupun wanita. Dalam memberikan panggilan untuk saudara laki-laki kandung orang Melayu Tanjungbalai, berbeda dengan daerah lain, yaitu abah sama artinya dengan abang adalah panggilan bagi saudara laki-laki kandung yang paling tua. Sedangkan panggilan untuk saudara perempuan sekandung yang paling tua adalah kakak. Panggilan untuk urutan saudara sekandung laki-laki maupun perempuan ada sembilan tingkatan panggilan. ${ }^{14}$ Anak yang pertama dipanggil Ulong atau Uwong. Anak yang kedua dipanggil ongah atau angah. Anak yang ketiga dipanggil alang. Anak yang keempat dipanggil uteh. Anak yang kelima dipanggil iyong. Anak yang keenam dipanggil anggah atau angga. Anak yang ketujuh dipanggil busu. Anak yang kedelapan dipanggil uncu/bungsu.

Panggilan untuk saudara sekandung dari pihak ayah adalah uwak untuk saudara laki-laki atau perempuan ayah yang tua, sedangkan saudara laki-laki ayah yang lebih muda dipanggil pakcik/ayah acik, bunde untuk saudara perempuan ayah yang lebih muda. Panggilan untuk saudara laki-laki atau perempuan yang lebih tua dari pihak ibu adalah uwak, kepada adik laki-laki ibu dipanggil incek, sedangkan adik perempuan ibu dipanggil ibu. Dalam hal perkawinan, anak bunde yang laki-laki dianjurkan menikah dengan anak perempuan dari uwak laki-laki, biasa disebut pasiloroan atau pariban dalam suku Batak. Sedangkan panggilan untuk kakek dan nenek adalah atok dan nenek atau andung.

\section{Adat Istiadat}

Pada dasarnya pengertian adat adalah "ketentuan yang mengatur tingkah laku

${ }^{14} Y u s c a n$, Adat Istiadat Perkawinan Melayu Sumatera Timur (Medan: PB. MABMI, 2007), h. 1. 
anggota masyarakat dalam segala aspek kehidupan manusia". ${ }^{15}$ Adat merupakan hukum yang tidak tertulis namun sekurang-kurangnya dapat dijadikan sebagai dasar maupun panduan dalam membentuk suatu aturan yang baku mengenai batasan perilaku yang baik dan buruk. Adat dan istiadat dalam hal ini adalah dua hal yang berbeda. Adat adalah aturan, kebiasaan-kebiasaan yang tumbuh dan terbentuk dari suatu masyarakat atau daerah yang dianggap memiliki nilai dan dijunjung serta dipatuhi masyarakat. Adat merupakan undang-undang dan peraturan negeri, sedangkan istiadat lebih memberatkan kepada upacara seperti perkawinan, kematian, dan pertabalan. ${ }^{16}$

Adat dan budaya berkembang secara turun temurun dari orang tua kepada anakanaknya. Akan tetapi pada saat ini pengembangan adat tersebut sudah tidak berjalan sebagaimana mestinya. Hal ini disebabkan banyaknya pengaruh budaya luar yang masuk melalui media informasi/masa. Adat dan budaya terbentuk dan berkembang sesuai dengan kebutuhan, situasi dan kondisi di suatu tempat. Setelah masuknya Islam ke Indonesia sebagai agama yang kemudian dianut dan ditaati oleh sebahagian besar bangsa Indonesia, untuk menyempurnakannya, adat dan budaya Melayu diselaraskan dengan ajaran Islam sebagaimana ungkapan yang berbunyi, "adatyang bersendikan syara', syara" mengikat adat, kuat agama kuat adat, kuat adat kuat agama."

Berdasarkan pendapat akar adat serta budayawan Melayu, adat Melayu dibagi atas beberapa tingkatan: adat yang sebenar adat, adat yang teradat, adat yang diadatkan, dan adat istiadat. Butir pertama adat sebenar adat adalah prinsip-prinsip adat Melayu yang tidak dapat berubah. Prinsip ini tersimpul dalam "adat bersendi syarak dan syarak bersendikan Kitabullah". Ketentuan-ketentuan adat yang bertentangan dengan hukum syarak tidak boleh digunakan lagi, karena hukum syara' lah yang dominan. Intinya, adat Melayu bersatu dengan ajaran Islam. Dasar adat Melayu menghendaki sandarannya kepada al-Qur'an dan hadis Nabi. Prinsip ini tidak dapat dihilangkan. Inilah yang disebut adat sebenar adat.

Butir kedua berkaitan dengan kebiasaan-kebiasaan yang kemudian menjadi bagian dari adat. Adat yang diadatkan adalah adat yang dibuat oleh penguasa pada satu kurun waktu tertentu. Masa berlakunya adat ini adalah selama belum diubah oleh penguasa berikutnya. Adat ini dapat berubah-ubah sesuai dengan perkembangan zaman dan situasi yang mendesak. Adat ini dapat dikatakan sebagai "pedoman pelaksanaan dan ketentuan adat". Jadi, adat yang diadatkan adalah adat yang dibuat dan lahir berdasarkan ketetapan penguasa (raja-raja, datuk-datuk dan penguasa). Selanjutnya petuah-petuah yang diajarkan dalam Gurindam Dua Belas ${ }^{17}$ juga memberikan bimbingan bagi anggota masyarakat Melayu tentang seharusnya orang Melayu bersikap dan bertingkah-laku sesuai dengan yang diinginkan

\footnotetext{
${ }^{15}$ Haron Daud, Sejarah Melayu: Satu Kajian Daripada Aspek Pensejarah Budaya (Selangor: Percetakan Dewan Bahasa, 1989), h. 19.

${ }^{16}$ Ahmad Dahlan, Sejarah Melayu (Jakarta: KPG, 2014), h. 551.

${ }^{17}$ Paul Bodholdt Pedersen, Darah Batak dan Jiwa Protestan (Jakarta: Gunung Mulia, 1975), h. 17 .
} 
oleh adat Melayu. Dalam perjalanan sejarah adat-istiadat Melayu, "adat yang diadatkan" mengalami berbagai perubahan dan variasi. Hampir dapat dipastikan bahwa adat ini merupakan adat yang paling banyak ragamnya, sesuai dengan wilayah tumbuh dan berkembangnya adat tersebut. "Adat yang diadatkan" yang terdapat di daerah Sumatera Utara beragam, karena di daerah Sumatera Utara pernah terdapat kerajaan-kerajaan yang tersebar dari kepulauan sampai ke hulu-hulu sungai. Setiap kerajaan tentu mempunyai corak dan variasinya yang disesuaikan dengan kondisi dan latar belakang sejarah, serta pengaruh yang masuk ke sana.

Butir ketiga berkaitan dengan sistem kepemimpinan. Adat yang teradat merupakan suatu kebiasaan yang diturunkan oleh orang-orang tua ke anak cucunya secara turun temurun. Karena itu, "adat yang teradat" ini pun dapat berubah sesuai dengan nilai-nilai baru yang berkembang. Tingkat adat nilai-nilai baru yang berkembang ini kemudian disebut sebagai tradisi.

Pelanggaran terhadap adat ini sanksinya tidak seberat kedua tingkat adat yang disebutkan di atas. Jika terjadi pelanggaran, maka orang yang melanggar hanya ditegur atau dinasihati oleh pemangku adat atau orang-orang yang dituakan dalam masyarakat. Namun, para pelanggar tetap dianggap sebagai orang yang kurang adab atau tidak tahu adat. Ketentuan adat ini biasanya tidak tertulis, sehingga pengukuhannya dilestarikan dalam ungkapan yang disebut "pepatah adat" atau "undang adat". Apabila terjadi kasus, maka diadakan musyawarah. Dari uraian di atas dapat disimpulkan bahwa ketentuan-ketentuan adat yang lebih dikenal sebagai hukum tidak tertulis telah diwariskan dalam bentuk undangundang, atau ungkapan. Butir keempat berkenaan dengan aktivitas-aktivitas upacara. Keempat stratifikasi adat Melayu ini, kemudian wajib berasas kepada syariat Islam.

\section{Asal Usul Etnis Batak Toba di Asahan}

Penduduk asli Asahan merupakan suku Batak Toba yang menempati daerah sepanjang Sungai Asahan. Masyarakat Batak ini merupakan keturunan Batak Toba yang bermigrasi di sepanjang aliran sungai Asahan untuk mencari lahan pertanian baru akibat semakin sempitnya lahan di sekitar Danau Toba. Ada tiga marga Batak Toba di Asahan yang merupakan suku asli, yaitu Margolang, Nahombang dan Pane (Sitorus).

Dijelaskan bahwa pada mulanya sekelompok orang-orang Batak bermukim di kawasan terpencil dan terpisah yang disebut dengan pardembanan yang letaknya di lembah sungai Asahan, lalu dari situ terjadi kemudian perpindahan dari daerah Toba ke daerah Asahan. ${ }^{18}$ Menurut cerita, setelah mereka tiba di daerah Asahan yang kebetulan penduduknya sebagian besar orang-orang Melayu yang beragama Islam, mereka berusaha berasimilasi dengan

${ }^{18}$ Clark E. Cunningham, The Postwar Migration of the Toba Batak to East Sumatera (New Haven: Yale University Cultural Report Series, 1958), h. 3, 
orang-orang setempat. Sebagai orang Batak Asahan yang berasal dari daerah Toba, mereka menyebut diri mereka sendiri sebagai orang Asahan, seolah-olah mereka memisahkan diri dari kelompok suku Batak Toba. ${ }^{19}$ Menurut sebagian pendapat, mereka merasa malu menyebut diri mereka sendiri sebagai orang Batak asli. Mungkin hal ini disebabkan oleh suatu keadaan yang harus menyesuaikan diri dengan penduduk asli setempat yang pada umumnya suku Melayu yang beragama Islam. Lama-kelamaan, sistem budaya dan kekerabatan Batak Toba yang selama ini melekat pada diri mereka semakin menghilang dari cara hidup mereka. Sejumlah besar dari mereka ini kemudian berpindah agama menjadi pemeluk agama Islam dan terintegrasi dengan orang Melayu Islam. Dalam jangka waktu yang agak lama, orang Batak pardembanan ini merasa enggan untuk menunjukkan identitas mereka sebagai orang Batak, misalnya menyebut marganya di depan umum. Keadaan ini berlangsung hingga menjelang kemerdekaan Indonesia pada tahun $1945 .^{20}$

Menurut Tengku Yose Rizal (Ketua PB MABMI Sumatera Utara), orang Batak Toba yang ada di Asahan ini adalah penduduk dari bukit yang sengaja turun dengan perahu menyusuri pinggir sungai sampai ke Bandar Pulo. Mereka membawa hasil tanaman rempahrempah untuk ditukar dengan kebutuhan lainnya di Bandar Pulo. ${ }^{21}$ Ada beberapa alasan mereka turun dari bukit. Pertama, desakan ekonomi, karena makin sulitnya kehidupan di tanah asal. Kedua, menukar hasil tanaman rempah-rempah dengan garam, ikan, dan kebutuhan lainnya. Ketiga, daerah perbukitan banyak yang tandus sehingga sulit untuk ditanami. Akibat lama bermukim di Asahan (Bandar Pulo), penduduk Batak Toba merasa enak tinggal di pinggir sungai Asahan, selain tanahnya yang subur, mudah mendapat kebutuhan seharihari seperti ikan. Akhirnya mereka menetap di Bandar Pulo.

Ketika Asahan dikuasai dan dipimpin oleh Sultan, penduduk Batak Toba ingin menetap dan memiliki Tanah serta rumah sendiri di Asahan. Mereka memohon kepada Sultan agar diberi sebidang tanah untuk bercocok tanam dan tempat tinggal. Sebagaimana dituturkan bapak Arifin, Batak Toba, "Leon ma di hami tanoi sotik" (Wahai Sultan, berilah kami tanah sedikit). Sultan, "Boi, ala masuk Melayu Maho" (boleh, tapi masuk Melayu lah kalian). ${ }^{22}$

Sejak saat itu penduduk Batak Toba banyak yang masuk Melayu (masuk Islam), berbudaya dan bahasa Melayu serta hidup dengan adat istiadat Melayu. Selain itu, mereka juga menghilangkan identitas Batak-nya (marga), dan hidup sebagai orang Melayu. Hal ini berlangsung sampai sekitar tahun 1946, ketika terjadi Revolusi Sosial di Sumatera Timur. Pada Revolusi Sosial tersebut seluruh kesultanan yang ada di Sumatera Timur mengalami

${ }^{19}$ Ibrahim Gultom, Agama Malim di Tanah Batak (Jakarta: Bumi Aksara, 2010), h. 34.

${ }^{20}$ Sinar, Bangun dan Runtuhnya, h. 120-129.

${ }^{21}$ Hasil wawancara dengan drs. H. Arifin (lahir di Bandar Pulo 27-09-1942), Ketua Forum Komunikasi Antar Lembaga Adat Cabang Asahan Tanjungbalai. Sampai sekarang, istilah masuk Melayu tetap dipakai di kota Asahan. Masuk Melayu berarti seseorang telah masuk Islam, atau bagi anak lelaki berarti sudah dikhitan.

${ }^{22}$ Hasil wawancara dengan Ketua Forum Komunikasi Kesultanan Asahan Tanjungbalai Bapak Raja Khairul Anwar (Raja Atan). 
situasi dan kondisi yang sama. Pada masa inilah mulai terjadi pergeseran dalam masyarakat, sebagian masyarakat yang berasal dari suku Batak, kembali memakai marga di belakang namanya, walaupun hanya satu huruf (S: Simargolang misalnya). Kemudian di awal tahun 1960-an masyarakat mulai memakai marga di belakang namanya, misalnya Arsyad Sitorus. Hal ini terkait dengan banyaknya keluarga Sultan yang dibunuh, dan masyarakat takut mengakui sebagai suku Melayu (berhubungan dengan keturunan sultan). ${ }^{23}$ Walaupun mereka telah memakai identitas sebagai batakan, tapi sebagian besar dari masyarakat tersebut tetap tidak bisa berbahasa maupun budaya Batak Toba. Mereka tetap berbahasa Melayu serta memakai budaya dan adat istiadat Melayu seperti dalam resepsi perkawinan.

\section{Akulturasi Budaya Melayu dan Batak Toba}

Sebelum kedatangan Islam, masyarakat Melayu di Kota Tanjungbalai terlebih dahulu mendapatkan sentuhan dari ajaran agama Hindu-Buddha, sebagaimana masyarakat Indonesia secara umum, pengaruh agama Hindu-Buddha bagi masyarakat Melayu sangatlah besar, baik dari aspek politik, ekonomi, sosial dan alam pemikiran masyarakat Melayu. Meski demikian, aliran kepercayaan awal masyarakat Nusantara termasuk orang Melayu yaitu animisme dan dinamisme tetap ada, kedatangan agama Islam, tidak serta merta menghapuskan aliran kepercayaan ini, namun dominasi ajaran Hindu-Buddha sangat kental dalam kehidupan masyarakat.

Kondisi di atas terus berlanjut hingga beratus tahun lamanya. Tatkala kedatangan Islam ke Indonesia, keberadaan ajaran agama Hindu-Buddha ini mulai mengalami kemerosotan, bukan berarti pengaruh agama Hindu-Buddha terhenti sampai di sini. Bahkan secara tidak langsung Islam ikut andil dalam melestarikan beberapa budaya agama Hindu-Budha di tengah masyarakat Melayu. Tetapi tentunya budaya tersebut telah disesuaikan dengan ajaran-ajaran agama Islam.

Sejak awal, pedagang-pedagang Muslim selalu diiringi oleh kelompok dagang dan ulama sufi yang mengembara dan menyebarkan Islam di berbagai kota di kepulauan Melayu. Dijelaskan berbagai sumber bahwa pada akhir abad ke 18, ulama Makkah dan India mengislamkan beberapa daerah di Sumatera. ${ }^{24}$ Brunei adalah negara Muslim pertama yang muncul di Borneo yang menerima Islam lewat hubungan dagang. Sebanding dengan Pasai dan Malaka, Aceh (1511-1650M) juga menjadi pusat studi Islam. ${ }^{25}$ Menurut Juynboll, ulama-ulama yang mengajar di Aceh berasal dari Mesir, Syria, dan India. ${ }^{26}$ Aceh menghasil-

\footnotetext{
${ }^{23}$ Andi Faisal Bakti, Nation Building: Kontribusi Muslim dalam Komunikasi Lintas Agama dan Budaya terhadap Kebangkitan Bangsa Indonesia (Jakarta: Churia Press, 2010), h. 7.

${ }^{24}$ Richard Winstedt, A History of Malay Literature (Singapore; MBRAS, 1940), h. 92.

${ }^{25}$ Th. W. Juynboll, "Atjeh," dalam Encyclopedia of Islam (Leiden: E.J.Brill, 1931).

${ }^{26}$ Taufik Abdullah, "The Pesantren in Historical Perspective," dalam Taufik Abdullah dan Sharon Shiddique (ed.). Islam and Society in Southeast Asia (Singapore: Institute of Southeast Asian Studies, 1986), h. 87.
} 
kan banyak penulis yang ahli dalam berbagai bidang pengetahuan Islam dan memberikan kontribusi pada literatur Melayu. Di antara penulis terkenal dari Aceh adalah Syamsuddin al-Sumatrani yang merupakan ulama besar yang mempunyai pengaruh kuat terhadap Sultan Iskandar Muda (w. 1636) ${ }^{27}$ Sultan Iskandar Muda adalah ayah dari Sultan Abdul Jalil Rahmad Syah (raja Asahan Tanjungbalai). ${ }^{28}$

Berdasarkan fakta sejarah ini, bisa diambil suatu pemahaman bahwa perkembangan Islam dilakukan dengan toleran, dalam artian pesan agama Islam sebagai rahmat untuk semesta alam, disampaikan dengan cara yang damai dan persuasif, dakwah dilakukan dengan memperhatikan unsur-unsur budaya lokal masyarakat melayu (dakwah kultural) atau dengan cara akulturasi budaya bukan dengan kekerasan. Di samping itu, dakwah juga dilakukan dengan kekuasaan (dakwah struktural). Dengan cara ini, ajaran Islam meresap ke dalam masyarakat Melayu, sehingga muncul idiom yang mengatakan bahwa "bicara Melayu berarti bicara tentang Islam dan budaya Melayu berarti budaya Islam." Ini suatu ungkapan yang menyatakan bahwa antara dunia Melayu dan Islam merupakan dua hal yang tidak terpisahkan.

Satu hal yang perlu dipahami bersama adalah bahwa akulturasi Islam di Indonesia, tidak hanya meliputi dunia Melayu saja, karena Islam juga sangat kental masuk dalam masyarakat Jawa. Namun tidak pernah orang mengatakan bahwa bicara Jawa berarti bicara Islam. Demikian juga halnya dengan proses masuknya budaya Melayu dalam masyarakat Batak Toba yang ada di kota Tanjungbalai, bukan lah suatu hal yang mudah. Akulturasi budaya Melayu dan Budaya Batak di kota ini melalui perjalanannya panjang, sehingga lahirnya budaya Melayu yang berbeda dengan Melayu di daerah lain. Melayu di daerah Tanjungbalai ini cenderung kasar baik dalam tutur kata maupun tingkah laku. Hal ini dikarenakan terjadinya akulturasi budaya Melayu dan budaya Batak. Salah satu bukti akulturasi budaya Melayu dan Batak Toba di kota Tanjungbalai ini adalah banyak nya kata-kata yang dipakai berasal dari bahasa Batak Toba.

Proses akulturasi budaya Melayu dan masyarakat Batak Toba Muslim di Tanjungbalai selain berdasarkan faktor di atas, terdapat beberapa persamaan budaya yang menyebabkan mudahnya proses akulturasi budaya Batak dan budaya Melayu di kota ini. Pertama, sistem kekerabatan suku Batak Toba dan Suku Melayu sama-sama menggunakan garis keturunan dari bapak (patrineal). Kaum laki-laki menjadi penentu dalam membentuk garis keturunan dan hubungan kekerabatan. Namun dalam beberapa adat istiadat terdapat perbedaan. Kedua, selain terdapat kesamaan dalam sistem kekerabatan, terdapat juga kesamaan antara suku Batak Toba dan suku Melayu dalam hal budaya, seperti ungkapan-ungkapan pantun dalam suku Melayu, juga terdapat ungkapan-ungkapan dalam suku Batak Toba. Budaya meratap dalam suku Batak Toba diadopsi oleh masyarakat Melayu Asahan Tanjungbalai

\footnotetext{
${ }^{27}$ Mohamad Arsjad, Thabal Mahkota Negeri Asahan (Tanjungbalai, t.p., 1933), h. 16-17.

${ }^{28}$ Samovar dan Porter, Komunikasi Lintas Budaya, h. 44-45.
} 
dalam bentuk Sinandong. Namun, sinandong ini dijadikan sebuah kesenian yang banyak diminati masyarakat Melayu sampai saat ini yaitu Sinandong Asahan yang diisi dengan kata-kata bernuansa Islami. Ketiga, menurut kajian sejarah dan antropologi, nenek moyang orang Batak sama dengan orang Melayu, berasal dari Hindia Belakang, dan penutur bahasa Austronesia.

\section{Enkulturasi Budaya Melayu pada Masyarakat Batak Toba Muslim}

Kebudayaan Melayu telah diperkenalkan pada masyarakat kota Tanjungbalai sejak masa Kesultanan Asahan I yang berdiri tahun 27 Desember 1620. Penduduk asli Asahan merupakan suku Batak Toba yang menempati daerah sepanjang Sungai Asahan. Masyarakat Batak ini merupakan keturunan Batak Toba yang bermigrasi dari daerah asalnya (Danau Toba, dan lainnya), dan kemudian menetap tinggal di Asahan. Mereka tinggal di Asahan untuk mencari lahan pertanian baru akibat semakin sempitnya lahan di sekitar Danau Toba. Ada tiga marga Batak Toba di Asahan yang merupakan suku asli, yaitu Margolang, Nahombang dan Pane (Sitorus).

Pasca Revolusi Sosial tahun 1946 di Sumatera Timur, terjadi pergeseran sikap dalam masyarakat dimana sebagian masyarakat yang berasal dari suku Batak kembali memakai marganya. Hal ini akibat banyaknya keturunan Sultan yang dibunuh, menimbulkan rasa ketakutan masyarakat untuk mengaku sebagai suku Melayu (berhubungan dengan keturunan sultan). Meski telah memakai kembali identitasnya, tetapi sebagian besar dari Batak Toba tidak sepenuhnya memahami budayanya. Mereka tetap berbahasa Melayu serta memakai budaya Melayu. Hal ini berlangsung sampai saat ini.

Berdasarkan hasil penelitian yang dilakukan di lapangan, bahwa proses penanaman nilai-nilai budaya Melayu terhadap masyarakat Batak Toba Muslim di kota Tanjungbalai melalui beberapa tahapan berikut. Pertama, nilai-nilai budaya Melayu pertama kali ditanamkan oleh Sultan Asahan I (pemerintah) yang pada masa pemerintahannya mewajibkan kepada siapa pun yang ingin tinggal menetap di daerah kekuasaannya harus masuk Melayu (berbudaya Melayu, berbahasa Melayu dan beragama Islam).

Kedua, proses penanaman nilai-nilai budaya Melayu di kota Tanjungbalai ini tidak terlepas dari pengaruh tokoh-tokoh agama (ulama) yang saat itu menanamkan ajaran Islam pada masyarakat Batak Toba yang telah masuk Islam. Pada masa kesultanan Asahan bahkan sampai era tahun 1980-an, masih banyak tokoh-tokoh agama (ulama dari Asahan Tanjungbalai) yang menanamkan ajaran Islam kepada masyarakat, sehingga masyarakat Batak Toba Muslim yang telah mendalami ajaran Islam, enggan untuk kembali kepada nilai-nilai budaya Batak.

Ketiga, penanaman nilai-nilai budaya Melayu pada masyarakat Batak Toba Muslim di kota Tanjungbalai selanjutnya adalah melalui keluarga. Setiap manusia lahir dalam sebuah keluarga, kelompok masyarakat tertentu yang telah memiliki nilai, norma, adat 
istiadat dan standar perilaku yang ditransmisikan melalui pembelajaran formal maupun informal. Pembelajaran informal tentang budaya kadang sulit dikenali, biasanya terjadi melalui interaksi antara orang tua dan anak (mencium tangan orang tua atau orang yang lebih tua misalnya), melalui pengamatan anak (melihat ibu memasak atau melihat ayah mencuci mobil). Sedangkan pembelajaran formal tentang budaya jauh lebih terstruktur dan mudah dikenali seperti. Namun terkadang sulit untuk membedakan antara pembelajaran formal dan informal, karena budaya mempengaruhi seseorang langsung mulai dari lahir, sehingga tidak menyadari pesan yang dikirimkan. Banyak masyarakat Batak Toba (baik laki-laki maupun perempuan) yang menikah dengan keturunan Sultan atau keturunan Melayu. Hal ini kemudian membuat anak-anak dari keturunan tersebut memahami budaya Melayu yang ditanamkan oleh keluarganya (ibu dan ayah) melalui pendidikan informal dalam keluarga.

Keempat, penanaman nilai-nilai budaya Melayu pada masyarakat Batak Toba Muslim di kota Tanjungbalai juga tidak lepas dari pengaruh tokoh-tokoh adat (ketua Adat). Budaya adalah pewarisan sosial yang mengandung pandangan yang sudah dikembangkan jauh sebelum mereka lahir. Masyarakat memiliki sejarah yang melampaui kehidupan seseorang, pandangan yang berkembang sepanjang waktu yang diajarkan pada setiap generasi dan kebenaran dilabuhkan dalam interaksi manusia jauh sebelum mereka meninggal. ${ }^{29}$

Salah satu karakter budaya adalah bahwa budaya itu dipelajari dari mulai lahir sampai akhir hidup manusia. Budaya dapat dipelajari karena interaksi antar manusia ditentukan oleh penggunaan simbol, bahasa verbal maupun non verbal. Tradisi, budaya, adat istiadat, kepercayaan, dan standar perilaku seseorang, semuanya diciptakan oleh hasil kreasi manusia dan bukan sekadar diwarisi secara instink, melainkan melalui proses pendidikan dengan cara-cara tertentu menurut kebudayaan masing-masing. ${ }^{30}$

Ikatan antara generasi yang diwariskan ini menyatakan hubungan yang jelas antara budaya dan komunikasi. Komunikasilah yang membuat budaya berkelanjutan. Kebiasaan, adat istiadat, prinsip, nilai, norma, dan tingkah laku dikomunikasikan kepada anggota yang lainnya. Ikatan antara generasi di masa lalu dan di masa depan sangat perlu, sehingga apabila ikatan putus, maka akan musnah suatu budaya.

Tokoh-tokoh adat Melayu yang ada di Asahan Tanjungbalai (baik yang berasal dari keturunan Sultan Asahan maupun bukan keturunan Melayu) tetap menanamkan dan melestarikan nilai-nilai budaya Melayu, baik melalui pemerintah maupun melalui forum komunikasi kesultanan Asahan Tanjungbalai. Hal ini karena kebudayaan mencakup semua hal yang dimiliki bersama oleh suatu masyarakat. Kebudayaan merupakan pandangan

${ }^{29}$ H.W. Gardiner dan C. Kosmitzki, Lives across Cultures: Cross Cultural Human Development, Cet. 4 (Boston: Allyn and Bacon, 2008), h. 66-67.

${ }^{30}$ Pasai misalnya mengislamkan Patani dengan cara memberikan obat kepada rajanya, mengislamkan Malaka dengan cara mengawinkan putri raja Pasai dengan raja Malaka (menurut versi Melayu). Lihat Bakti, Nation Building, h. xiv. 
hidup dari sekelompok orang dalam bentuk perilaku, kepercayaan, nilai, dan simbol-simbol yang mereka terima tanpa sadar atau tanpa dipikirkan, yang semua itu diwariskan melalui proses komunikasi dan peniruan dari satu generasi kepada generasi berikutnya.

\section{Masuk dan Perkembangan Nilai-nilai Budaya Melayu}

Sebelum kerajaan-kerajaan Islam berdiri di Nusantara, Islam menyebar luas dengan berbagai cara, baik melalui perdagangan maupun melalui perkawinan. ${ }^{31}$ Islam mungkin telah diperkenalkan pada awal abad hijriah oleh pedagang Asia, Arab, Persia, India, atau pedagang Cina. Para pedagang yang telah menjadi Muslim ini ada yang bertempat tinggal tetap di wilayah Indonesia, kawin campur, dan mengadopsi gaya hidup setempat, sehingga mereka menjadi orang Jawa dan Melayu. Berdasarkan pendapat beberapa sejarawan, kemungkinan Islam masuk ke Nusantara melalui rute perdagangan yang terletak antara Arab dan Cina. Pelabuhan-pelabuhan Nusantara adalah tempat transit bagi para pedagang. Pedagang yang membawa Islam bukan hanya datang dari Arab, karena pedagang-pedagang Muslim ada juga yang berasal dari India, Gujarat, Melabar, Bengal dan Persia. Pedagang Persia kemungkinan besar juga banyak andil dalam penyebaran Islam di Nusantara. Hal ini dibuktikan dengan adanya beberapa kosa kata Melayu yang berasal dari bahasa Persia. Negara lain seperti Cina, Mesir dan Turki juga punya kontribusi lewat perdagangan dalam memperkenalkan Islam di Indonesia.

Lewat penyebaran Islam ke seluruh kawasan Nusantara, nilai-nilai Islam secara berangsur-angsur dapat menyatu dengan tradisi, norma, dan kehidupan sehari-hari bangsa Indonesia. Kerelaan mereka mengizinkan orang asing untuk tinggal di negeri mereka menunjukkan bahwa mereka siap membagi kehidupan bersama. Pendirian beberapa kerajaan Islam di beberapa pulau Indonesia seperti pulau Sumatera, adalah bukti begitu kuatnya pengaruh Islam di negeri ini. Islam sebagai faktor eksternal berhasil menyatukan kelompokkelompok etnis yang terdiri atas beberapa suku yang ada di Sumatera. Arus aktivitas pedagang, pengembaraan ulama, dan penggunaan bahasa Melayu merupakan tulang punggung bagi integrasi budaya tersebut.

Sampai saat ini keluarga keturunan Batak Toba yang ada di Tanjungbalai Asahan masih memakai adat budaya Melayu, dan tidak bisa berbahasa Batak. Keluarga Batak Toba yang ada di Asahan masih berbudaya Melayu karena beberapa hal. Pertama, faktor agama, bahwa ajaran Islam yang tertanam di keluarga membuat mereka enggan kembali memakai budaya asli mereka (Batak). Kedua, faktor perkawinan, bahwa sebagian dari keturunan Batak Toba ini menikah dengan keturunan di luar Batak Toba atau dengan keturunan Sultan (bangsa Melayu), sehingga dalam keluarga tidak memakai budaya Batak. Ketiga, faktor lingkungan, bahwa bukan hanya keturunan Batak Toba, etnis lain (Karo, Jawa,

${ }^{31}$ M.C. Ricklef, A History of Modern Indonesia c. a. 1300 to the Present (Bloomington: Indiana University Press, 1981). 
dan Minang) yang menetap di Asahan juga hidup dengan adat istiadat dan budaya Melayu, sehingga lingkungan sekitar hanya mengenal budaya Melayu, dalam semua segi kehidupan mulai kelahiran, dan perkawinan. Demikianlah besarnya pengaruh Budaya Melayu pada masyarakat Tanjungbalai Asahan sampai saat ini.

Dalam masyarakat multi etnik seperti di Kota Tanjungbalai, bahasa Melayu merupakan bahasa dominan yang digunakan dalam pergaulan sosial. Secara historis, dominasi bahasa Melayu ini terkait dengan masa awal keberadaan orang Melayu di kota tersebut. Seperti halnya kota-kota maritim lainnya di tanah air, Tanjungbalai yang merupakan salah satu kota bandar maritim telah menjadikan bahasa Melayu sebagai bahasa pergaulan (lingua franca) penduduk setempat.

Menurut teori, bahasa merupakan salah satu identitas kelompok etnik akan tampak jelas dalam suatu interaksi sosial masyarakat majemuk. Salah satu identitas orang Melayu adalah bahasa Melayu. Orang-orang Melayu di Tanjungbalai menguasai dengan baik bahasa Melayu, dan bahasa Indonesia. Penggunaan bahasa-bahasa tersebut ditentukan oleh konteks interaksi yang mereka hadapi. Dalam pergaulan sehari-hari, seperti di tempat-tempat publik, bahasa Melayu merupakan bahasa komunikasi dan interaksi sosial yang digunakan oleh orang-orang Tanjungbalai. Bahasa Indonesia akan digunakan oleh orang-orang Melayu Tanjungbalai jika mereka berurusan dengan instansi atau dalam situasi resmi.

Konteks historis dan geografis di atas telah menempatkan bahasa Melayu memiliki kedudukan dan peranan yang penting dalam kehidupan sosial budaya masyarakat Tanjungbalai. Karena bahasa Melayu merupakan referensi komunikasi sosial, para pendatang pun seperti orang-orang Batak dan etnis lain harus belajar dan menggunakan bahasa tersebut dengan baik. Pemahaman yang baik terhadap bahasa Melayu sering mendorong timbulnya gejala interferensi leksikal ketika orang-orang Tanjungbalai berbicara dalam bahasa Melayu di lingkungan internalnya atau ketika mereka berbahasa Indonesia dengan orang yang baru dikenalnya.

Sebagai sarana interaksi sosial, penguasaan bahasa Melayu tidak hanya untuk mengekspresikan diri, tetapi juga menjadi media integrasi sosial dengan orang-orang Melayu atau penduduk Tanjungbalai. Dalam konteks integrasi sosial, bahasa bukan sekedar untuk meningkatkan "daya keberterimaan" masyarakat lokal terhadap kehadiran dan eksistensi orang-orang luar, memudahkan pemahaman terhadap budaya masyarakat lokal, tetapi juga menjadi sarana untuk mempermudah akses terhadap sumber daya ekonomi lokal.

Selain dengan menggunakan bahasa dalam artian yang sebenarnya, Islamisasi di tanah Melayu juga melalui media "bahasa" dalam artian "bahasa budaya". Bahasa budaya yang dimaksud adalah dengan cara pendekatan budaya dalam wujud akulturasi. Dengan "bahasa budaya" inilah, Islamisasi di tanah melayu meresap hingga ke dalam kehidupan masyarakat, hingga lapisan paling bawah sekalipun. Proses Islamisasi dan perkembangan budaya serta peradaban Islam dalam hal ini memainkan peranan yang signifikan dalam sejarah kesultanan Melayu di Indonesia. Termasuk sejarah kesultanan Melayu yang ada 
di Sumatera Timur seperti Kesultanan Deli, Kesultanan Langkat, Kesultanan Serdang, Kesultanan Kualuh, Kesultanan Bilah, dan Kesultanan Asahan.

\section{Penutup}

Proses komunikasi penanaman nilai-nilai budaya Melayu bagi etnis Batak Toba Muslim di Tanjungbalai berawal dari pemerintahan (Sultan Asahan I) yang memerintah sebelum kemerdekaan Indonesia. Para ulama dan tokoh adat juga berperan besar dalam proses penanaman nilai-nilai budaya Melayu pada masyarakat di kota Tanjungbalai. Melalui agama, nilai-nilai dan norma akan berubah berdasarkan ajaran agama yang dianut. Di samping itu, terdapat beberapa hal dalam adat budaya Batak yang tidak diperbolehkan dalam agama Islam. Proses masuk dan berkembangnya nilai-nilai budaya Melayu di kota Tanjungbalai, selain melalui kedatangan Sultan Aceh (Sultan Iskandar Muda) yang singgah sebentar untuk beristirahat dalam perjalanan, juga masuk melalui pedagangpedagang Muslim yang selalu diiringi oleh kelompok dagang dan ulama sufi yang mengembara dan menyebarkan Islam di berbagai kota di kepulauan Melayu. Proses akulturasi budaya Melayu dan budaya Batak Toba di kota Tanjungbalai terjadi melalui proses panjang, namun akulturasi tersebut dapat terjadi dengan baik karena di antara kedua budaya memiliki beberapa persamaan, disamping juga terdapat perbedaan, sehingga akulturasi budaya ini melahirkan budaya Melayu yang cenderung keras seperti halnya sifat masyarakat Batak Toba. Sebagai penutup, saran-saran berikut perlu diperhatikan. Pertama, pengenalan kembali terhadap nilai-nilai budaya sangat penting bagi pelestarian sebuah budaya, dan diharapkan akan ada peneliti berikutnya yang meneliti sejarah kesultanan yang ada di Indonesia secara umum, Sumatera khususnya. Kedua, diharapkan pemerintah daerah untuk melestarikan khazanah budaya yang terdapat di daerah-daerah setempat, agar generasi berikutnya mengenal sejarah suku dan budaya mereka. Ketiga, penelitian terhadap komunikasi penanaman nilai-nilai sebuah budaya sangatlah penting, mengingat semakin banyaknya nilai-nilai budaya yang hilang dari masyarakat akibat masuknya budaya asing.

\section{Pustaka Acuan}

Abdullah, Taufik. "The Pesantren in Historical Perspective," dalam Taufik Abdullah dan Sharon Shiddique (ed.). Islam and Society in Southeast Asia. Singapore: Institute of Southeast Asian Studies, 1986.

Arsjad, Mohamad. Thabal Mahkota Negeri Asahan. Tanjungbalai, t.p., 1933.

Bakti, Andi Faisal. Nation Building: Kontribusi Muslim dalam Komunikasi Lintas Agama dan Budaya terhadap Kebangkitan Bangsa Indonesia. Jakarta: Churia Press, 2010.

Basyarsah II, Tengku Luckman Sinar. Bangun dan Runtuhnya Kerajaan Melayu di Sumatera Timur. Medan: Yayasan Kesultanan Serdang, 2006. 
Chung, You-Jin \& Jayashree Mohanty. "Between Two Worlds in Asia: Korean Youth in Singapore," dalam Springer Science Business Media Dordrecht, 29 July 2014.

Cunningham, Clark E. The Postwar Migration of the Toba Batak to East Sumatera. New Haven: Yale University Cultural Report Series, 1958.

Dahlan, Ahmad. Sejarah Melayu. Jakarta: KPG, 2014.

Daud, Haron. Sejarah Melayu: Satu Kajian Daripada Aspek Pensejarah Budaya. Selangor: Percetakan Dewan Bahasa, 1989.

Departemen Pendidikan Nasional. Kamus Umum Bahasa Indonesia. Jakarta: Balai Pustaka, 2006.

Gardiner, H.W. dan C. Kosmitzki. Lives across Cultures: Cross Cultural Human Development, Cet. 4. Boston: Allyn and Bacon, 2008.

Gultom, Ibrahim. Agama Malim di Tanah Batak. Jakarta: Bumi Aksara, 2010.

Juynboll, Th. W. "Atjeh," dalam Encyclopedia of Islam. Leiden: E.J.Brill, 1931.

Koentjaraningrat. Pengantar Antropologi, Jilid II. Jakarta: Rineka Cipta, 2005.

Kota Tanjungbalai Dalam Angka 2014 (Tanjungbalai in Figures 2014). Tanjungbalai: Badan Pusat Statistik Kota Tanjungbalai, 2014.

Marpaung, Watni. Mutiara Kota Kerang Tanjungbalai: Mengungkap Sejarah Asal Usul Nama, Adat Istiadat, Tradisi, Makanan Daerah, Kesenian, Pendidikan, dan Sosial Budaya. Medan: Badan Perpustakaan, Arsip dan Dokumentasi Provinsi Sumatera Utara, 2011.

Marshall, Joan \& Natalie Foster. "Between Belonging: Habitus and The Migration Experince," dalam Canadian Geographer, Spring, 2002, 46. 1.

Nagata, Judith. The Impact of the Islamic Revival (Dakwah) on the Religious Culture of Malaysia, dalam Bruce Matthews dan Judith Nagata (ed.), Religion, Values, and Development in Southeast Asia. Singapore: Institute of Southeast Asian Studies, 1986.

Pedersen, Paul Bodholdt. Darah Batak dan Jiwa Protestan. Jakarta: Gunung Mulia, 1975.

Ramanathan, Vijayasarathi. "Values, Behaviour and Identity: Acculturation of Indian Immigrant Men in Australia," dalam Springer Science Business Media Dordrecht, 24 June 2014.

Ricklef, M.C. A History of Modern Indonesia c, 1300 to the Present. Bloomington: Indiana University Press, 1981.

Samovar, Larry A. dan Richard E. Porter. Komunikasi Lintas Budaya, terj. Indri Margaretha Sidabalok. Jakarta: Salemba Humanika, 2010.

Schwartz, Montgomery \& Briones. "The Role of Identity in Acculturation among Immigrant People: Theoretical Propositions, Empirical Questions, and Applied Recommendations," dalam Human Development, 49, 1-30.

Soekanto, Soerjono. Sosiologi: Suatu Pengantar. Jakarta: Rajawali Pers, 1987.

West, Richard dan Lynn H. Turner. Pengantar Teori Komunikasi: Analisis dan Aplikasi, terj. Maria Natalia Damayanti Maer. Jakarta: Salemba Humanika, 2009. 
Mailin: Akulturasi Nilai Budaya Melayu dan Batak Toba

Winstedt, Richard. A History of Malay Literature. Singapore: MBRAS, 1940.

Yuscan. Adat Istiadat Perkawinan Melayu Sumatera Timur. Medan: PB. MABMI, 2007. 